\title{
Rationalism about Autobiography
}

\section{Samuel Clark}

Department of Politics, Philosophy, and Religion

Lancaster University

\begin{abstract}
:
Autobiography is a distinctive and valuable kind of reasoning towards ethical knowledge. But how can autobiography be ethical reasoning? I distinguish four ways in which autobiography can be merely involved in reasoning: as clue to authorial intentions; as container for conventional reasoning; as historical data; and as thought experiment. I then show how autobiography can itself be reasoning by investigating its generic form. Autobiographies are particular, enabling vivid display of and education in value-suffused perception. They are diachronic, enabling critique by ironic contrast. And they are compositional, enabling sense-making by placing in a temporal structure. But these features don't distinguish autobiographies from novels. Should we therefore accept a deflationary account of a fourth generic feature of autobiographies, that they are self-reflective? I instead pursue a more ambitious account of self-reflection and the distinctively autobiographical reasoning it enables, involving a realism constraint, a reflexive explanation constraint, and unique address to first-person problems of the self. I conclude with an interpretation of an example work of autobiographical reasoning, Siegfried Sassoon's Memoirs of George Sherston, against the idea that self-owning is necessary to the good human life.
\end{abstract}


Forthcoming in Philosophy $\mathcal{E}$ Literature. Please cite that version, not this one.

\section{Introduction}

Autobiography is a distinctive and valuable kind of reasoning towards ethical knowledge. We can rationally learn something about ourselves, as human beings and as individuals who find ourselves in a world suffused with value and its demands, by reading and thinking through this particular kind of text. Autobiographies educate, rather than merely proselytizing or manipulating, about ethics, and they are therefore an important but underused resource for moral philosophy.

Call this view rationalism about autobiography. But how can autobiography be reasoning? Why be a rationalist about autobiography? I answer in two parts. First, I work by contrast: I describe various ways in which autobiographies can be involved in reasoning, in order to pick out the distinctive way in which they enact a form of reasoning in themselves. Second, I give an account of that form of reasoning by investigating the formal features of the autobiography as a genre, partly by comparison and contrast with two other literary genres, the novel and the biography.

I will be asked: what do you mean by reasoning and by ethical here? My full answer to that question is the account of autobiography as ethical reasoning which I develop in the body of the paper, but I will make some initial attention-focusing remarks.

Reasoning is engagement in any of various social practices with three basic features. First, they involve change in belief, desire, feeling, or action. Second, they have standards of correctness, such that at minimum the ideas of being reason-guided, and of improvement-change for the better-in belief, desire, feeling, or action, apply [1]. And third, those engaging in them both perform as, and address themselves to, active, responsive fellow reasoners, not just passive listeners. Because reasoning is social, any one reasoner's engagement in it is always incomplete, inviting response.

Social practices of reasoning include formal debate; writing and publishing; speech-giving; reading with pencil in hand; attending lectures and taking part in seminars; listening to testimony; trying out new identities, rituals, and situations; pursuing topics through Wikipedia; arguing in pubs and coffee shops.

The typical activities these practices involve include-and this is an equally incomplete list-deduction; induction; inference to the best explanation; making distinctions; making comparisons and contrasts; telling stories and jokes; asserting and checking facts; forks; reductios; redirecting attention; identifying new questions; satire; utopian construction.

Change in belief, desire, feeling, or action can come about in non-reasonguided ways, so not everything is reasoning: compare threats, mere rhetoric, 
or mechanical manipulation of affect and disposition [2]. But there are many kinds of reasoning, because there are many ways of appealing to reasons, as above, and many kinds of reasons to which one can appeal: particular and general facts; affectual and perceptual reactions; second-order reasons such as reasons to take other reasons as more or less weighty; reasons of 'thin' rationality such as consistency within the systems of beliefs and of desires, and in the relation of both to actions [3]; procedural reasons [4].

The ethical is the domain of Socrates's question - how should one live? [5] and of its surrounding problems, traditionally including such interconnected questions as: What am I? Who am I? Why did I do what I did? Did I do the right or rational thing? What should I do now, or with the rest of my life? What is good? Has my life gone well? What should I become, and how? What does my life mean, if it means anything? Can I make it meaningful? Am I the owner of my life, or am I alienated from it? Do I live under my own command, or am I just the victim of circumstance? Does my life hang together as a whole? What changes can I survive?

There is no problem about autobiographies being concerned with these widesense ethical questions: consider John Stuart Mill's investigation of his own unhappiness in the context of human flourishing [6]; or Tim O'Brien's attempt to understand why he went to fight as a draftee in Vietnam instead of deserting; or Doris Lessing's account of her decision to leave her children behind in Rhodesia and come to England to be a novelist.

The harder question is: do these and other autobiographies address these questions by reasoning about them, or in some other way? I now develop an account of what autobiographies do which shows that and how they reason. The first part of that argument describes some ways in which autobiography can be involved in reasoning, as contrastive boundary-markers to the positive account of autobiographical reasoning I go on to develop.

\section{Autobiography as clue and as container}

My first contrast case is autobiography as clue. Thinkers' autobiographies could offer clues for interpreters of their 'official' thought. Reading Mill's Autobiography on his mental crisis and recovery could help us to understand his account of happiness in Utilitarianism [9]. Richard Wollheim's memoir Germs could help us understand his William James lectures The Thread of Life [10]. This is potentially interesting, but it is not autobiography as reasoning: it's autobiography as a way of helping us to motivate and choose between interpretations of reasoning done elsewhere.

My second contrast case is autobiography as container. The autobiographies of some philosophers-Collingwood's An Autobiography, for example [11]- 
contain explicit reasoning of the kind a treatise in philosophy might, but wrapped in an autobiographical narrative for cosmetic, historical, or other purposes. Such reasoning in autobiographies requires no special treatment: we could read the philosophical parts of Collingwood's autobiography as we'd read any other work of philosophy. Perhaps that reading should be contextual rather than purely textual, but if it should, it should for reasons which apply across the board, not just to autobiographies. This again isn't autobiography as reasoning. It's addressing a text presented as an autobiography as two distinct things: the reasoning, and the life-story which contains it, and which can be disposed of like the wrapper round chocolate.

\section{Autobiography as historical data}

My third contrast case is autobiography as historical data: as information about past lives on a par with other textual sources. This is problematic, because autobiographies are terrible data: they're not transparent windows through which we observe the facts of an autobiographer's life, but highly-motivated interpretations of that life, replete with bias, partiality, individual perspective, and all the general unreliabilities of memory worsened by the pressure to defend one's self-concept against one's failures and out-of-character moments.

But perhaps this worry is overstated. In the mass and in the context of other data, autobiographies are no worse than other historical evidence, and historians have developed techniques to deal with such problems. For one example of this use of autobiography, Jonathan Rose uses large numbers of mostly-unpublished memoirs from the eighteenth to the twentieth centuries, together with library records and the minutes of self-improvement societies and workingmen's institutes, to uncover the history of British working class self-help and autodidacticism [12]. But this is again autobiography used in reasoning rather than autobiography as reasoning: the reasoning picked out here is going on in the analysis of trends in the mass, not in the data in which those trends are found.

\section{Autobiography as thought experiment}

My fourth contrast case is autobiography as thought experiment, or as source material for thought experiments. Philosophers could use autobiographical narratives in the places and ways we currently use invented or fictionalized examples. Take as an example Bernard Williams's account of Paul Gauguin's abandonment of his family to pursue his art [13], which, as Williams is clear, makes no claim to historical accuracy [14]. We could make the same argument about moral luck if we replaced this example with Lessing's autobiographical 
account, already mentioned, of leaving her children to pursue her ambition to be a novelist.

The canonical role for thought experiments is in attempts at analysis: propose necessary and sufficient conditions for the proper application of some concept; test and refine it with apparent counter-examples; aim at reflective equilibrium between the general analysis and particular cases [15]. But there is no advantage for this project in replacing Williams's Gauguin with Lessing's Lessing, nor in general in using autobiographical rather than fictional examples. And there is the disadvantage that if we did so, we would be unable to tweak our counter-examples to put pressure on the precise conditions of interest, without heading in the direction of invention anyway. Why spend time looking through autobiographies for a good counterexample, when we could just make one up, or just modify the one we have without regard to historical truth? If what's in question is whether our analysis correctly defines the borders of usage, whether the test cases are hypothetical or not is in itself irrelevant. If the test case is a very long way from the ordinary cases of use, there is a worry whether our intuitions can get any purchase. But this is a problem about strangeness, not about accuracy: we can describe many untrue but ordinary cases, and identify real cases where intuition is silent or confused.

However, thought experiments can be understood more broadly as exemplary stories, used for the various purposes stories are used for in ordinary discussion: to make something vivid, to dramatize a problem, to gain a sympathetic hearing, to get a laugh, as a mnemonic, to focus on some features of a situation and push others out of the limelight, to remind people of something they already believe, to make a generalization concrete, to give some plausibility to a surprising claim, to draw the reader's attention to their own psychology (as in many of Hume's exemplary stories), to provoke selfexperimentation in the reader, to render the ordinary alien (as in satire and the anthropological exotic).

Autobiographies can provide starting places for such exemplary stories, but in general they're not ideal for these roles, for two reasons. First, they are under-schematized: just because of their detail and complexity, arising from the detail and complexity of actual lives, they are less good at the narrowlydirected work of dramatizing and spotlighting. Consider the way that an autobiographical story told and retold for persuasive purposes-by a politician, for example - tends to be honed into a schematized anecdote by the pressure of use. Second, they are partly constrained by a requirement of realism (to which I return later), where thought experiments' work is often helped by their being hypothetical. Both of these features of autobiographies therefore pull against the typical uses of thought experiments understood 
Forthcoming in Philosophy \& Literature. Please cite that version, not this one.

broadly as exemplary stories. So, thought experiment isn't the distinctive kind of reasoning I want to pick out in autobiography.

\section{Form enables reasoning}

I now argue that autobiographies enact a distinctively autobiographical style of reasoning through their generic form. Autobiographical texts' formal features enable authors to do distinctive things with them, just as the formal features of other genres of writing enable authors to do different things with them. For example, the dialogue-more canonical in Western and in Indian philosophy than the autobiography-variously enables self-concealment, taming opponents by straw-manning them, self-effacement, self-revelation, and the dramatization of moral and political ideals [17]. The now-standard treatise enables a distinctive professional rigour and explicitness, and an engagement in philosophy as Kuhnian normal science, with shared problems, agreed methods, and a productive division of labour.

The paradigmatic autobiographical form, in contrast to these other forms, is particular diachronic compositional self-reflection. I describe these four features and the reasoning they enable individually. This breaking up into separate formal features and what reasoning they can do is artificial: autobiographies don't typically do one of these things and then later another, but reason using all of their formal resources at once. But dismantling the mechanism will help to see how it works. My running example in explaining how these features enable reasoning is Siegfried Sassoon's autobiographical trilogy Memoirs of a Fox-Hunting Man, Memoirs of an Infantry Officer, and Sherston's Progress, which I'll bring in as I need it.

\section{Particular reasoning}

Autobiography is about particulars: individual people, the things they do, the things which happen to them, the contexts they find themselves in, what their experiences do to them; Sassoon, his doubts and decisions, his friends and mentors, his war experience. These vividly display complex value-laden perceptions of a world filled with the good and bad, right and wrong, pleasing and unpleasing, beautiful and ugly, awe-inspiring and contemptible, respected and despised, loved and hated. Sassoon, in Memoirs of a FoxHunting Man, brings his prewar world to life with exceptional clarity and emotional grip.

How is this reasoning? It displays, and draws the reader into, perceiving value; and by doing so it educates sensibility. This is not deductive reasoning, but it does give reasons, by showing and by attempting to help the reader to see. If we're reasoning about the value of something, we can appeal to 
consistency with other value judgements, but I can't demonstratively argue you into enjoying or being awed by something that you don't or aren't: all I can do is direct your attention in what I hope is the right time and context. I could play you John Coltrane's Ascension as a way of initiating you into free jazz. You could take me up Loughrigg Fell on a clear day as a way of helping me to fall in love with the Lake District. Of course these attempts to provide reasons for attitudes can fail: an audience may be unmoved this time or ever, and will sometimes be right to be unmoved. But all that is true of other kinds of reasoning too.

Sassoon attempts to give us reason to value the life he describes - to see it as good and as containing goods. For me in particular as his audience, he succeeds in doing what I wouldn't have thought possible: getting me to see fox-hunting as having some good in it, at least in the joyful skill in crosscountry riding which it involves (a good which doesn't outweigh the bads of its cruelty and class snobbery).

How does the display of value in the particular address my three basic features of reasoning? There is change here in the development of perceptual sensibility. There is a standard of correctness in the idea that vivid display can be an education of that sensibility, such that we can come to see better, to be more competent judges of value. And there is invitation to respond in that educational encounter.

\section{Diachronic reasoning}

Autobiography is diachronic. It looks back from one time to a sequence of events over the extended past. An autobiographer as narrator turns her attention on her own historical past, as distinct from attending to herself now. This move offers critical perspective through self-doubling, by opening an ironic gap between a narrator's and a protagonist's perception and understanding. Sassoon's autobiography takes up that ironic perspective, from his position writing after fighting in the trenches, on his innocent younger self, who has no idea of what's going to happen to him, of what losses he can suffer, or of the cruelty and stupidity which is hidden in his prelapsarian world, about to be revealed.

How is this reasoning? It is critique by contrast, as also used, for example, in satire and in utopian texts [21]. It sets up a dialectic between perspectives, but not equal perspectives - not just 'you see it one way, I see it another' - because the narrator's perspective is later and was partly produced by the earlier protagonist, and there is therefore potential for argumentative movement towards seeing better. This allows for the past actions and events described in 
Forthcoming in Philosophy $\mathcal{E}$ Literature. Please cite that version, not this one.

the autobiography to be set against ideals, norms, or at least improved understandings.

Sassoon ironizes his own naïve failure to grasp himself, his world, and their fragility in the face of war, and by doing so gives us reason to think differently about our own degree of self-knowledge and about our own uncontrolled vulnerability to circumstance. In Memoirs of an Infantry Officer in particular, Sassoon maps his gradual shift towards revolt against the war by moving backwards and forwards between reinhabiting his perspective at the time and taking up an external perspective on it.

How does diachronic critique address my three basic features of reasoning? There is change here in drawing us as audience along with a development over time, by displaying the contrast between an original and an improved understanding, and change in our own understanding of a protagonist by showing a later perspective on that protagonist. There is a standard of correctness in the possibility of seeing not just differently, but better: by gaining the later perspective, we learn something not grasped by the protagonist at the earlier time. And there is invitation to respond in the opportunity to inhabit the perspectives of narrator and of protagonist, and thereby to learn also to distance ourselves from, and to criticize by contrast, our own earlier selves.

\section{Compositional reasoning}

Autobiography is compositional: it places its actions and events in a temporal whole, showing them as parts of a complex structure with an overall shape, and thereby explaining or making sense of them. An autobiography is paradigmatically the story of a life understood as a whole, not merely a chronicle of its temporal parts. The structure through which Sassoon makes sense of his life is from innocence to experience. In that he is like many other soldier autobiographers: the idea of battlefield education or combat epiphany is a common trope in modern military memoirs [22].

How is composition reasoning? It makes sense of individual actions and events by locating them in a larger structure. Causal explanation is one casewe make sense of something by explaining how it came about-but we can also make sense, in autobiographies, by appeal to agents' reasons (if those are different from causes) and by appeal to the meaning of individual actions and events in relation to one another and to an overarching purpose or significance. Sassoon does not merely report a transition from innocence to experience over his lifetime: he makes sense of himself and of what happened to him by understanding individual actions and events as parts of that innocence-to-experience structure. 
We should note here that the compositional shape uncovered in or given to a life by an autobiography need not be a narrative shape, or at least that narrative shape need not do any sense-making work. Autobiographies are typically narratives in the thin sense that they are tellings of connected temporal sequences of actions and events. But this is a fairly trivial feature: many autobiographies have compositional shapes which are much richer and more particular than narrative's generic shapes, and which require an actual structure-the growth of some distinctive potential into its expression, for example-not just its telling. That structure is obviously narratable-or one couldn't write an autobiography about it - but being the content of a narrative is not the same thing as being a narrative. Autobiographers make sense of their lives not just by narrating them, but by appeal to the particular temporal structures in and circumstances of those lives, which they narrate.

How does compositional sense-making address my three basic features of reasoning? There is change here in coming to see discrete events as cohering in a larger structure, and thereby as explained, made sense of, or made meaningful. There is a standard of correctness in the question whether that structure does explain: does it successfully make sense of the events it composes? And there is invitation to respond in the open expectation of alternative explanations and attempts at sense-making (perhaps Sassoon's life could be better understood in other terms, for example those offered by his various biographers [23]); and even in the possible challenge that no sense can be found in the life (perhaps Sassoon's life is nothing more than a jumble of events).

\section{An objection: autobiographies are just novels}

At this point I need to deal with an objection: so far, nothing I've said distinguishes autobiographies from novels, nor the ethical reasoning of autobiographies from the ethical reasoning of novels. Consider James's The Golden Bowl as interpreted by Martha Nussbaum [24]. It displays value-laden particulars. It takes up an ironic and critical perspective on its characters: James as narrator tells the reader much more than any one character sees, and he criticizes Maggie Verver in the early part of the novel as childish, puritanical, and imperceptive. It composes actions and events into a whole: the novel is Maggie's bildungsroman. What makes the difference, if there is one, is the final generic feature of autobiography which I want to pick out: self-reflection. Autobiographies are works of reflective attention. The autobiographer takes up a multiplied but self-referential point of view, turning her attention as subject on herself as object.

One deflationary line to take here is that there is no important difference between autobiographies and novels. Autobiography is just a sub-genre of the 
novel, and any novel could do autobiography's work in reasoning [25]. And in fact I have been deliberately slightly misleading about Sassoon's 'autobiography': it could equally be called his trilogy of novels about a protagonist called 'George Sherston'. They're written in an intimate firstpersonal voice, and Sherston's life is very like (although not identical with) Sassoon's, but they're only ambiguously autobiography.

The easy thought for me is that yes, a novel could do this work - to the extent that it has the paradigmatic autobiographical form of particular diachronic composition plus the formal structure of self-reflection. On this line of thought, 'self-reflection' does not require metaphysical identity between author, narrator, and protagonist, but only the adoption of the literary devices of firstpersonal voice and free indirect style: sympathetic but distanced examination of the protagonist which moves subtly between inhabiting her internal perspective and adopting an external perspective on her [26]. So, Memoirs of a Fox-Hunting Man begins 'My childhood was a queer and not altogether happy one. Circumstances conspired to make me shy and solitary. My father and mother died before I was capable of remembering them. I was an only child, entrusted to the care of an unmarried aunt who lived quietly in the country' [27]. And in the same form, Great Expectations begins 'My father's family name being Pirrip, and my christian name Philip, my infant tongue could make of both names nothing longer or more explicit than Pip. So I called myself Pip, and came to be called Pip. I give Pirrip as my father's name, on the authority of his tombstone and my sister-Mrs Joe Gargery, who married the blacksmith' [28].

It's not an accident that novels and autobiographies have such similar forms and can therefore do such similar work: the two traditions have the same prehistory. Early novels were presented as memoirs or confessions. The fuller title of Robinson Crusoe is The Life of Robinson Crusoe, of York, Mariner... Written by Himself, for example, and Defoe presents Crusoe's story as a true confession rather than a fiction.

On this line of thought, there's no need to be concerned with marking boundaries between an autobiography, an autobiographical novel, and an ordinarily fictional novel, and ambiguous cases like Sassoon's are unproblematic. The extent to which some text is autobiographical is just a matter of the degree to which it adopts a particular literary style.

\section{Self-reflective reasoning}

Rather than take this easy route, I do want to argue that autobiography is distinctive, in three ways arising out of its self-reflective form. 
First, and as already mentioned, autobiographies have a realism constraint: they are supposed to be sensitive to what actually happened in a way novels need not be. Autobiography is self-reflection, the self-reflective author is real, and she really has a life in which some things happened and others did not. Of course, not all autobiographies live up to this demand. For example, James Frey's A Million Little Pieces is a failed self-reflection: Frey not only fictionalized his experience by making his protagonist's life different in specific ways from his own - which might have been a useful tactic for selfreflection, as for Sassoon-but fictionalized it in a deeply clichéd, and therefore insensitive to reality and unrevealing way [29]. The problem with Frey's 'memoir' is not merely that it does not accurately represent the facts of his life, it's that the specific misrepresentations only obscure Frey's particularity, replacing self-representation and self-interpretation with stock forms and characters: the macho substitute father, the damaged but sexy angel, the sinner's redemption [30].

How is this reasoning? It adds weight to any lessons about human ethical life we take from autobiographies over such lessons from novels (or from failed autobiographies), because how we imagine human ethical life is systematically distorted and infested with myths like the ones which vitiate Frey's attempt at self-knowledge. That is, the realism constraint on autobiographies, together with the ordinary epistemic reasons we have for believing or not believing their protestations of accuracy, provide second-order reasons for weighing reasons in particular ways.

This constraint distinguishes autobiographies from novels, but not from biographies. We could say that an autobiographer does not have a special kind of access to her own life, just-normally-a more capacious access than other potential narrators of it [31]. Autobiographical reports are not special: autobiography is a reflectively-styled sub-type of life-writing, not fundamentally distinct from biography. Richard Holmes deploys the same skills he used as a biographer of Coleridge and Shelley to investigate himself in his memoir Footsteps [32].

If I do not have a privileged kind of access to my own life, unavailable to others, then someone else might be able to give a better account of my life than I could myself. Perhaps this biographer has information or capacities that I lack: Oliver Sacks can tell more about his amnesiac patients than they can tell about themselves [33]. Perhaps the biographer is better able to make sense of the causal processes of my life than I am competent to, or can bear to. Angus Wilson's The Strange Ride of Rudyard Kipling explains Kipling far better than Kipling himself managed [34]. But there is reason to distinguish autobiographies from biographies. 
Second, autobiographies have a reflexive explanation constraint: the person who takes up the reflexive stance was made by the history she describes. The protagonist of an autobiography isn't just grammatically identical with its narrator, she actually turned into that narrator and into the author who performs both protagonist and narrator. She is investigating the enabling conditions of her own activity. The autobiographical narrator can be ironically separated from the protagonist, because we can be so separated from our past selves, but can't be completely other than the protagonist. There has to be a line of explanation from protagonist to narrator and to that narrator's ability self-reflectively to understand and narrate her life. To see this point in its crudest form, imagine an 'autobiography' in which the protagonist ' $\mathrm{I}$ ' dies in the second chapter.

How is this reasoning? It constrains the composition of autobiography compared with the composition of biographies as well as novels, because what happens to the protagonist has to be able to explain the narrator who reflects on her. That is, again, this constraint provides second-order reasons for re-weighing reasons.

The third way in which autobiographies are distinctive is not a constraint, but an opportunity. Autobiographical self-reflection enables reasoning about questions of the autobiographer's self-knowledge: her particular self, its particular good, and her relations to herself over time. These are the wide-sense ethical questions I noted at the start-What am I? Who am I? Why did I do what I did? Did I do the right or rational thing? and so on-given a distinctively first-personal, reflective sense. We could call them the first-person problems of the self.

Autobiography is a distinctively first-personal kind of reasoning about these problems of self-knowledge. For one example, some autobiographies investigate how to discover, take on, or constitute oneself as a whole rather than a mere temporal sequence-or why one can't so unify or integrate or own oneself. This self-reflective reasoning attempts to reconcile, or to give up on reconciling, the autobiographer's first-person perspective now with the third-person perspective on the actions and events of her own life extended over time. Different autobiographies give different accounts of this whole-life unity or its impossibility. Edmund Gosse's Father and Son argues for understanding the unity of his life as given by an underlying developmental structure in which latent potential is constrained before being woken and expressed. Edwin Muir's An Autobiography argues for understanding his temporal life as an illusion behind which stands the real, timeless self [36]. Maxine Hong Kingston's The Woman Warrior argues against any unification, by displaying the multiple identities within, and the multiple connections outwards from, her persona as a Chinese-American woman. This is reasoning, not something else, because it reveals and offers reasons for 
Forthcoming in Philosophy \& Literature. Please cite that version, not this one.

understanding selves in the different ways which particular autobiographies display.

\section{Sassoon's rejection of unity}

I can't do more here than sketch one example of autobiographical reasoning, by returning to Sassoon's Memoirs.

Consider the view that the good life for a human being involves self-owning: that taking ownership of, or accepting, or endorsing, or taking responsibility for one's life as a whole is necessary for that life's going well; that being alienated from oneself is a threat to the life of flourishing [38]. This is the strong claim that such self-owning is at least partly constitutive of living well as a person, not just, for example, the weaker instrumental claim that it makes one happier to own one's life (or that the alienated are unhappy) combined with the hedonistic claim that the good life is the life of happiness.

Sassoon's George Sherston trilogy reasons against this view, by describing and enacting three kinds of self-alienation which it presents as necessary to Sassoon's understanding and fully living his life. To own their subjects fully would be to falsify his experience and to fail to live his life successfully.

First, Sassoon focusses on cases of synchronic self-awareness, in which consciousness is doubled such that he (masked as George Sherston) observes himself in the moment. For example, Sassoon's account of his spontaneous and foolhardy one-man attack on a German trench at Mametz Wood moves from singleness-'all my feelings tightened and contracted to a single intention' - to doubledness - 'While I was running I pulled the safety-pin out of a Mills' bomb; my right hand being loaded, I did the same for my left. I mention this because I was obliged to extract the second safety-pin with my teeth, and the grating sensation reminded me that I was half way across and not so reckless as I had been when I started' [39]. Sassoon's descriptions of others' battle experience, when he ventriloquizes them, present them as much more unified and unselfconscious than his own. But on his own account, battle was for him an experience not of owning himself, but of moving between being singly present and not under his own rational control in one moment, and observing himself from a somewhat distanced perspective the next [40].

Second, Sassoon focusses on cases of diachronic self-awareness, in which he as narrator looks back and comments, often critically, on himself as protagonist. For example, Sherston talks to an old friend of his Aunt's: 'I even went so far as to assert that I wouldn't have missed this war for anything. It brought things home to one somehow, I remarked, frowning portentously as I lit my pipe, and forgetting for the moment what a mercy it had been when it 
brought me home myself' (IO, pp. 375-6). Sometimes Sassoon makes his ironic perspective explicit: 'What I am writing now is the result of a bird's-eye view of the past' (IO, p. 378). But this self-separation by time is neither a straightforward rejection of identity-narrator and protagonist are not different people-nor a straightforward ownership, given Sassoon's distanced amusement and embarrassment at his gauche younger self.

Third, Sassoon presents Sherston's and therefore his life as deeply marked by a structural disunity. His move from innocence to experience, which I described above, is both epistemically and personally transformative [41]. Living through a transformative experience provides a kind of knowledge only available by first-personal acquaintance. Only a parent knows what it's like for her to have a child; only those who have fought know what combat is like for them (the claim is not that nothing can be known third-personally about these and other experiences, it's that not everything can be known that way). Second, such an experience is personally transformative. I am a different person after becoming a parent; Sassoon is a different person after his baptism of fire. Sassoon is therefore in one sense two people rather than one, with a transformative break between them. That break is dramatized by the split between the prewar idyll of Memoirs of a Fox-Hunting Man and the war of Memoirs of an Infantry Officer. But this is again not a total rejection of identity between the innocent and the experienced Sassoon. It is a recognition of the possible extent of change in a single life, and a rejection of simple ownership. The older Sassoon, changed by the war, can't straightforwardly own the callow young 'fox-hunting man', because too much has happened. But the older can't reject the younger entirely either, because the older was made by the younger and out of transformative experience. That's the complexity and tension of the relation between first-personal and third-personal perspectives on the self which powers and shapes Sassoon's Memoirs as a whole.

Beside these three explicit kinds of self-alienation, there is a fourth kind of alienation enacted but not described. This is the alienation of those parts of Sassoon's life missing from Memoirs: his parents, poetry, and love life. Sherston is brought up by his aunt after being orphaned, but Sassoon was brought up by his mother after she and his father were estranged. Sherston apparently writes nothing but letters and diary entries, but Sassoon's war poetry-written in the trenches over the period covered by Memoirs of an Infantry Officer and in Craiglockhart War Hospital over that covered by Sherston's Progress - made him both famous in his time, and a central figure in our default understanding of World War I [42]. Sherston has no love life to speak of beyond admiration of simple, single-minded riders and officers, but Sassoon was more intimately involved with several of these characters' reallife counterparts, and was-some of the time-willing to acknowledge and celebrate his homosexuality. What Sassoon chooses not to put into the George 
Forthcoming in Philosophy $\mathcal{E}$ Literature. Please cite that version, not this one.

Sherston books is indicative of his deep doubledness and the complexity of his carefully half-distanced relation to his own life.

Sassoon's refusal of straightforward self-owning is reasoning both towards a more complex attitude to his own life, and towards a general critique of the idea that one could just own oneself outright over a whole life-could have one relation of owning to all that one is and has done. That idea is simplistic: actual lives are far more complex in their ownerships, identifications, distancings, alienations, and rejections, and are not thereby failures.

This isn't a conclusive response to the idea of self-owning. But what I am trying to show here is that autobiography is ethical reasoning, not that the particular reasoning of Memoirs of George Sherston is correct. Defenders of a self-owning view can have plenty to say in reply: all I have meant to show is that Sassoon's autobiography engages in reasoning with them and invites their reasoned replies.

\section{Summary}

Summing up: autobiography is ethical reasoning in multiple ways connected to its formal features. It reasons about value of various kinds by vivid presentation of value-laden particulars. It enacts self-criticism and aims at self-knowledge through ironic self-separation. It makes sense of the sequence of actions and events which makes up a whole life. And, by being selfreflective in a more than grammatical sense, it constrains its reasoning with requirements of realism and reflexive explanation, and it enables reasoning about the first-person problems of the self.

What is at stake in calling this reasoning is that it involves change in belief, desire, feeling, or action; that it has standards of correctness, such that the ideas of being reason-guided, and of improvement in belief, desire, feeling, or action, apply; and that those engaging in it both perform as, and address themselves to, active, responsive fellow reasoners. Autobiography's effects are not merely emotional or rhetorical, and autobiographical content is not mere material for reasoning done elsewhere. Autobiographical reasoning is admittedly not complete or conclusive: it requires interpretation and invites challenge, both of which I offer. But in that way it is no different from other kinds of reasoning.

Autobiography, as this distinctive kind of reasoning about human ethical life, is therefore an important but underused resource for moral philosophy. 
Forthcoming in Philosophy $\mathcal{E}$ Literature. Please cite that version, not this one.

\section{Notes}

[1] I take the idea that reasoning involves reason-guided change from Gilbert Harman, Change in View: Principles of Reasoning (Cambridge MA: MIT Press, 1986).

[2] The situationist literature in psychology is full of examples of the last. See John Doris, Lack of Character: Personality and Moral Behavior (Cambridge: Cambridge University Press, 1995) for summary and application.

[3] Jon Elster, Sour Grapes: Studies in the Subversion of Rationality (with a new preface, Cambridge: Cambridge University Press 2016), p. 1.

[4] I mean to remain neutral here in two large debates about reasons. First, reductionism: are reasons to be explained by something else, for example desires or the structure of the rational will, or are they primitive? See T. M. Scanlon, Being Realistic About Reasons (Oxford: Oxford University Press, 2014). Second, motivation: must one's reasons for action, in particular, be connected with one's actual or possible desires? See Bernard Williams, 'Internal and External Reasons' in Moral Luck: Philosophical Papers 1973-1980 (Cambridge: Cambridge University Press, 1981), pp. 101-13. Nothing I say here is intended to commit me to any view about either of these.

[5] Bernard Williams, Ethics and the Limits of Philosophy (with a commentary on the text by A.W. Moore, London: Routledge, 2006), p. 1.

[6] John Stuart Mill, Autobiography in John M. Robson \& Jack Stillinger eds, Collected Works volume 1: Autobiography and Literary Essays (Toronto: University of Toronto Press, 1981), pp. 1-290.

[7] Tim O’Brien, If I Die in a Combat Zone (London: Calder and Boyars, 1973).

[8] Doris Lessing, Under My Skin: Volume One of My Autobiography, to 1949 (London: Harper Collins, 1994).

[9] Samuel Clark, 'Love, Poetry, and the Good Life: Mill's Autobiography and Perfectionist Ethics', Inquiry 53(2010): 565-578.

[10] Richard Wollheim, Germs: A Memoir of Childhood (London: Waywiser, 2004); The Thread of Life (Cambridge: Cambridge University Press, 1984).

[11] R. G. Collingwood, An Autobiography (Oxford: Clarendon Press, 1939).

[12] Jonathan Rose, The Intellectual Life of the British Working Classes (New Haven: Yale University Press, 2002).

[13] Bernard Williams, 'Moral Luck' in Moral Luck, pp. 20-39.

[14] Compare Françoise Cachin, Gauguin: The Quest for Paradise (London: Thames \& Hudson, 1992); David Sweetman, Paul Gauguin: A Complete Life (London: Hodder \& Stoughton, 1995). 
Forthcoming in Philosophy $\mathcal{E}$ Literature. Please cite that version, not this one.

[15] One classic example of this method is Judith Jarvis Thomson, 'The Trolley Problem', The Yale Law Journal 94(1985): 1395-1415.

[16] This distinction between being schematized and being hypothetical as typical features of thought experiments is due to John Martin Fischer, 'Stories' in Our Stories: Essays on Life, Death, and Free Will (Oxford: Oxford University Press, 2009), pp. 129-143.

[17] Samuel Clark, 'Hume's Uses of Dialogue', Hume Studies 39(2013): 61-76.

[18] In Siegfried Sassoon, The Complete Memoirs of George Sherston (London: Faber and Faber, 1937).

[19] This list of perceived values is influenced by Elizabeth Anderson, Value in Ethics and Economics (Cambridge MA: Harvard University Press, 1993).

[20] This paragraph draws on the literature of moral particularism, especially David McNaughton, Moral Vision: An Introduction to Ethics (Oxford: Blackwell, 1988) and Martha C. Nussbaum, Love's Knowledge: Essays on Philosophy and Literature (Oxford: Oxford University Press, 1990). But I am only taking on the ideas of value-perception and of education in it, and can remain neutral about the further question whether all moral reasoning is particularistic, or whether it also involves general principles.

[21] Samuel Clark, Living Without Domination: The Possibility of an Anarchist Utopia (new edn, Routledge 2016).

[22] On which see Yuval Harari, 'Martial Illusions: War and Disillusionment in Twentieth-Century and Renaissance Military Memoirs', The Journal of Military History 69(2005): 43-72 and The Ultimate Experience: Battlefield Revelations and the Making of Modern War Culture, 1450-2000 (Basingstoke: Palgrave Macmillan, 2008).

[23] Max Egremont, Siegfried Sassoon: A Biography (London: Picador, 2004); John Stuart Roberts, Siegfried Sassoon (1886-1967) (London: Metro, 2005); Jean Moorcroft Wilson, Siegfried Sassoon: Soldier, Poet, Lover, Friend (London: Duckworth, 2013).

[24] Henry James, The Golden Bowl ed. Ruth Bernard Yeazell (London: Penguin, 2009); Nussbaum, Love's Knowledge, essays 4 and 5.

[25] Paul Fussell, in The Great War and Modern Memory (25 $5^{\text {th }}$ anniversary edn, Oxford: Oxford University Press, 2000), argues that the classic war memoirs of the First World War should be understood as autobiographical novels in the same genre as James Joyce's Portrait of the Artist as a Young Man or Samuel Butler's The Way of All Flesh.

[26] Peter Goldie, The Mess Inside: Narrative, Emotion, and the Mind (Oxford: Oxford University Press, 2012), chapter 2. James Wood, How Fiction Works (London: Vintage, 2009). 
Forthcoming in Philosophy $\mathcal{E}$ Literature. Please cite that version, not this one.

[27] Sassoon, Complete Memoirs, p. 1.

[28] Charles Dickens, Great Expectations ed. Charlotte Mitchell (London: Penguin, 1996), p. 3.

[29] James Frey, A Million Little Pieces (London: John Murray, 2003).

[30] John Dolan effectively skewers Frey's artistic and reflective failures in 'A Million Pieces of Shit', The Exile, May 292003 (online, accessed 7 July 2016). Chapter 11 of Ben Yagoda, Memoir: A History (New York: Riverhead Books, 2009) puts the discovery of Frey's lies in the context of other such scandals about false autobiographies.

[31] Compare Gilbert Ryle's argument that 'Self-consciousness, if the word is to be used at all, must not be described on the hallowed para-optical model, as a torch that illuminates itself by beams of its own light reflected from a mirror in its own insides. On the contrary it is simply a special case of an ordinary more or less efficient handling of a less or more honest and intelligent witness.' - The Concept of Mind (Harmondsworth: Peregrine, 1963), p. 186.

[32] Richard Holmes, Footsteps: Memoirs of a Romantic Biographer (London: Harper Perennial, 2005).

[33] For example Oliver Sacks, 'The Lost Mariner' in The Man Who Mistook His Wife for a Hat (London: Picador, 1986), pp. 22-41 and 'The Last Hippie' in An Anthropologist on Mars (London: Picador, 1995), pp. 39-72.

[34] Angus Wilson, The Strange Ride of Rudyard Kipling: His Life and Works (Harmondsworth: Penguin, 1979). Compare Rudyard Kipling, Something of Myself: And Other Autobiographical Writings ed. Thomas Pinney (Cambridge: Cambridge University Press, 1990).

[35] Edmund Gosse, Father and Son ed. Peter Abbs (London: Penguin, 1983). See further Clark, 'Love, Poetry, and the Good Life'; Samuel Clark, 'Pleasure as Self-Discovery', Ratio 25(2012): 260-276.

[36] Edwin Muir, An Autobiography (Edinburgh: Canongate, 1993).

[37] Maxine Hong Kingston, The Woman Warrior: Memoirs of a Girlhood among Ghosts (New York: Knopf, 1976).

[38] There are versions of this idea in, for example, John J. Davenport, Narrative Identity, Autonomy, and Mortality: from Frankfurt and Macintyre to Kierkegaard (New York: Routledge, 2012); Harry Frankfurt et al., Taking Ourselves Seriously $\mathcal{E}$ Getting it Right ed. Debra Satz (Stanford: Stanford University Press, 2006); Connie Rosati, 'The Story of a Life', Social Philosophy and Policy 30(2013): 21-50. 
Forthcoming in Philosophy \& Literature. Please cite that version, not this one.

[39] Sassoon, Memoirs of an Infantry Officer in Complete Memoirs, pp. 343-4. Hereafter abreviated ' $I O$ '.

[40] This movement between immediacy and doubledness is not unique to battle. On a similar movement in craft work, see Samuel Clark, 'Good Work', Journal of Applied Philosophy 34(2017): 61-73.

[41] I draw here on L. A. Paul, Transformative Experience (Oxford: Oxford University Press, 2014).

[42] Siegfried Sassoon, Collected Poems 1908-1956 (London: Faber and Faber, 1984). See especially Counter-Attack and Picture-Show. For the reception and influence of Sassoon, and of other poets and autobiographers of the war, see Fussell, The Great War and Modern Memory. 